\title{
Cultural Comparison of Students' Union Construction between Universities Inside and Outside Mainland China
}

\author{
Ou Xiangli ${ }^{1}$ \\ ${ }^{1}$ Director of Student Affairs Department, Jinan University, Guangzhou, China \\ Correspondence: Ou Xiangli, Room 318, Administration Building, Jinan University, No. 601 Huang Pu Road, \\ 510632, Guangzhou, China.
}

Received: December 5, 2017

doi:10.5539/ass.v14n2p126
Accepted: December 18, 2017 Online Published: January 29, 2018

URL: https://doi.org/10.5539/ass.v14n2p126

\begin{abstract}
The higher education has developed a new normal, which has brought both new opportunities and requirements on the progress of students' union at universities. Through the comparison of students' union construction between universities inside and outside mainland China, this paper analyzes student organizations of universities in terms of their development, establishment and approval, organizational structure, forms of activities and financial source and differences of management and development, drawing on the successful experience of which, the paper introduced suggestions to student organizations on the following aspects: improving management and system establishment for healthy development; increasing investment and support to strengthening engagement in society and innovating the contents of activities with characteristics for high quality; establishing an international communication platform while opening up for development. With all these efforts, this paper hopes to provide reference on the ways of building students' unions of universities in mainland China.
\end{abstract}

Keywords: Universities inside and outside mainland China; students' union; culture

\section{Introduction}

Initiated by college students, the students' union, serving as the significant bridge and link relating student body and university authorities, boasts an indispensable part of university student organizations and leverages its positive role in facilitating campus culture construction, optimizing educational environment and enhancing students of their qualities. Besides, with unique advantages, the students' union can make great contributions to the campus harmony through varied accesses. The writer conducted researches by visiting universities in America, HK, Macao, Taiwan and Guangdong Province. According to the researches, due to different social background, sense of value, economy and idea of running college, there are some disparities in management and cultural construction of students' union between universities inside and outside mainland China. Through comparative studies on these disparities, this paper provides the students' unions at universities in mainland China with reference and learning of management and construction in line with their realities.

\section{Situation of University Student Societies Inside and Outside Mainland China}

\subsection{Overviews of University Students' Unions Outside Mainland China}

At universities outside mainland China, the students' union and student organizations are all identified as "student societies", generally referring to social groups formed by college students voluntarily, which mainly include university-based and faculty-based students' unions together with their sub-organizations which are divided by interests like sports, academic exchange and public service, as well as some news media and associations in faculties of universities. Students of American universities are usually full of passion towards the student societies and in return the societies give priority to dedicated, passionate and excellent students from various fields with solid academic foundation and potential leadership. Take the University of Florida(UF) as an example. The student association of UF is located in the center of the campus, dubbed as "heart of campus". With the space provided by University of Florida Trade Union Committee, members of the student association share social activities with members in the community of UF and learn from them apart from attending meetings and enjoying their campus life. Most of the student societies established in the University possess their own independent websites, which not only intensifies the students' sense of engagement but improves their knowledge and abilities, indeed a successful move of university running in America. 
Based on the cases of The University of HK (HKU), University of Macao (UM)and National Taiwan University(NTU), the Table 1 below shows a certain similarity between universities in HK, Macao and Taiwan and universities in the United States. Universities of both sides have many student societies with distinct characteristics and goals. The HK University Students' Union (HKUSU) is a non-profit organization founded in 1912 serving more than 16,000 students of the University of HK. In 1949, the Union was registered as a financially and administratively independent social organization, out of the regulation and control of the HKU. There are 130 student societies affiliated to HKUSU. These student societies can be categorized into several groups: sports clubs, culture and entertainment association, academic societies, religious societies, societies for public welfare, hall students' association and among the others, from which members of HKUSU can choose to join in according to their interests. Similar to HKUSU, University of Macao Students' Union (UMSU) embraces 80 sub-organizations, including faculty-based students' union, academic association, cultural association and sports association. However, the organizational structure of the National Taiwan University Student Association (NTUSA) seems quite simple, composed of only student societies based on faculties and departments, in total 86 affiliated organizations. But what should be emphasized is that the students in NTU are so explorative that they connected the NTUSA with social practice, bringing full play to the individual interests of the NTUSA members and enhancing their practical abilities.

Table 1. Outline of University Students' Unions in HK, Macao and Taiwan

\begin{tabular}{|c|c|c|c|c|c|}
\hline $\begin{array}{l}\text { Name of } \\
\text { Students' } \\
\text { Union }\end{array}$ & $\begin{array}{l}\text { Establishment } \\
\text { Year of } \\
\text { University }\end{array}$ & $\begin{array}{l}\text { Establishment } \\
\text { Year of } \\
\text { Students' Union }\end{array}$ & $\begin{array}{c}\text { Number of } \\
\text { Sub-organization }\end{array}$ & Category of Sub-organization & Aim \\
\hline $\begin{array}{l}\text { HK } \\
\text { University } \\
\text { Students' } \\
\text { Union }\end{array}$ & 1910 & 1912 & 130 & $\begin{array}{c}\text { Faculty and Academic } \\
\text { Societies, Hall Students' } \\
\text { Associations, Sports Clubs } \\
\text { (forming Sports Association, } \\
\text { HKUSU), Cultural Clubs } \\
\text { (forming Cultural } \\
\text { Association, HKUSU) and } \\
\text { Independent Clubs (forming } \\
\text { Independent Clubs } \\
\text { Association, HKUSU) }\end{array}$ & $\begin{array}{l}\text { To promote the } \\
\text { welfare of the } \\
\text { student body }\end{array}$ \\
\hline $\begin{array}{l}\text { University of } \\
\text { Macao } \\
\text { Students } \\
\text { Union }\end{array}$ & 1981 & 1993 & 80 & $\begin{array}{l}\text { Faculty-based Students' } \\
\text { Union, Academic } \\
\text { Association, Cultural } \\
\text { Association and Sports } \\
\text { Association }\end{array}$ & $\begin{array}{l}\text { With the } \\
\text { democratic spirit } \\
\text { and self- } \\
\text { governance, we } \\
\text { should be } \\
\text { committed to the } \\
\text { core values of } \\
\text { "Humanity, } \\
\text { Integrity, } \\
\text { Propriety, Wisdom } \\
\text { and Sincerity" }\end{array}$ \\
\hline $\begin{array}{l}\text { National } \\
\text { Taiwan } \\
\text { University } \\
\text { Student } \\
\text { Association }\end{array}$ & 1928 & 1988 & 86 & $\begin{array}{c}\text { Faculty-based (or } \\
\text { department-based) Students' } \\
\text { Union }\end{array}$ & $\begin{array}{c}\text { To fight for a } \\
\text { better National } \\
\text { Taiwan University } \\
\text { with higher } \\
\text { equality and } \\
\text { quality }\end{array}$ \\
\hline
\end{tabular}

\subsection{Overviews of University Students'Unions Inside Mainland China}

At universities inside mainland China, student societies generally mean the organizations that built on students' interests who carry out activities in accordance with regulations. Nevertheless, the students' union of a university usually refers to student organizations leaded by leaders of the School Party Committee and founded with the guidance of Youth League Committee of a faculty or university. Therefore, it differs from the student societies. The following Table 2 proves that, compared with the students' union at universities outside mainland China, the unions at universities in Guangdong Province seem relatively simple and are very few in number, leading to many common issues against their development. However, with the growing attention to developing university 
students' unions, the unions in Guangdong province has achieved some good results in constructing campus cultural activities. In Jinan University (JNU), the students' union held some unique brand activities successively demonstrating that the university is worthy of the name of "prestigious university for Overseas Chinese", which are Jinan University International Folk Dance Competition, Chinese Culture Festival and the Overseas Chinese Students Cup, all highly appreciated by the students. The South China Agricultural University (SCAU) has consecutively held an activity named "An Appointment with University President", which provides a more direct and effective access for students to reflect the hot issues. What's more, the Sun Yat-sen University (SYSU) arranged a series of lectures named "Growing up with Our School - Old Story About SYSU", whose excellence were recognized unanimously by the students as well.

Table 2. Outline of University Students' Unions in Guangdong Province

\begin{tabular}{|c|c|c|c|c|c|}
\hline $\begin{array}{c}\text { Name of } \\
\text { Students' Union }\end{array}$ & $\begin{array}{l}\text { Establishment } \\
\text { Year of } \\
\text { University }\end{array}$ & $\begin{array}{l}\text { Establishment } \\
\text { Year of } \\
\text { Students' Union }\end{array}$ & $\begin{array}{c}\text { Number of } \\
\text { Sub-organization }\end{array}$ & $\begin{array}{c}\text { Category of } \\
\text { Sub-organization }\end{array}$ & Aim \\
\hline $\begin{array}{c}\text { Student Union } \\
\text { of Sun Yat-sen } \\
\text { University }\end{array}$ & 1924 & 1924 & 59 & $\begin{array}{l}\text { Faculty-based students' } \\
\text { union campus-based } \\
\text { students' union }\end{array}$ & $\begin{array}{l}\text { Share caring, } \\
\text { enhance } \\
\text { individual } \\
\text { growth }\end{array}$ \\
\hline $\begin{array}{l}\text { Jinan University } \\
\text { Students' Union }\end{array}$ & 1906 & 1978 & 29 & $\begin{array}{l}\text { Faculty-based students' } \\
\text { unioncampus-based } \\
\text { students' union }\end{array}$ & $\begin{array}{l}\text { Be solidary and } \\
\text { progressive, } \\
\text { serving } \\
\text { "Jinannese" }\end{array}$ \\
\hline $\begin{array}{l}\text { South China } \\
\text { Agricultural } \\
\text { University } \\
\text { Student Union }\end{array}$ & 1909 & 1956 & 18 & $\begin{array}{c}\text { Faculty-based students' } \\
\text { union }\end{array}$ & $\begin{array}{l}\text { Serve the } \\
\text { students }\end{array}$ \\
\hline
\end{tabular}

\section{Comparison of Students' Union Construction Between Universities Inside and Outside Mainland China}

\subsection{The Way of Selecting the President of Students' Union}

The American university students' union is a student organization completely independent of the university administration. They obey the separation of powers, with the union divided into three branches, each with separate and independent powers and areas of responsibility so that the mutual checks and balances are provided. The annual general election can be regarded as a big event in campus in the school year. The president of a student union is elected by all the students directly. The election for the president is generally held in spring so that he or she can make full preparation for the next term. And most of the candidates are sophomores or juniors. The students' union of HK and Macao universities has become an independent legal organization registered directly with the government of HK SAR. Although it adopts an independent organization, management, finance and operation. In practice, the department for student affairs is still responsible for the management, supervision and guidance of the unions. The way of open selection is imposed in selecting the president at HK and Macao universities, in which all students vote anonymously. The newly-elected president is entitled to reorganize the members of the union. (Zhu, Liu, \& Zhang, 2008) As for the students' union in Taiwan, according to the "Regulation of Student Association of National Taiwan University", the NTUSA holds presidential general election annually in May, and the president of National Taiwan University Students Union is directly elected by students.

Table 3. The way of selecting the president of student societies of universities inside and outside Mainland China

\begin{tabular}{|c|c|c|}
\hline $\begin{array}{l}\text { The Way of Electing } \\
\text { President }\end{array}$ & $\begin{array}{l}\text { Nominated by the Higher Organizational Department and } \\
\text { students' union of the last term through consultation and } \\
\text { elected by deputies through democratic election. }\end{array}$ & $\begin{array}{l}\text { Directly selected by all } \\
\text { students through democratic } \\
\text { election voluntarily. }\end{array}$ \\
\hline $\begin{array}{l}\text { Universities Inside Mainland } \\
\text { China }\end{array}$ & $\begin{array}{c}\text { Communist Youth League, Students' Union, Association of } \\
\text { Student Societies }\end{array}$ & No \\
\hline $\begin{array}{l}\text { Universities Outside } \\
\text { Mainland China }\end{array}$ & No such case & $\begin{array}{c}\text { University-based students' } \\
\text { union }\end{array}$ \\
\hline
\end{tabular}

Compared with the students' union outside mainland China, the counterpart inside mainland China follows the 
principle of democratic centralism. At first, deputies of the students' congress will be elected by students from each faculty through democratic election. Then, members of the committee of students' union, members of standing committee and the president will be elected by the deputies. Basically, the president and vice president of the students' union will be nominated by the students' union of the last term and other organizations through consultation, and then elected by a new plenary session. The whole procedure will be finished after the review of Youth League Committee of the University and the approval of the school CPC Party Committee and the provincial Students' Federation.

\subsection{Organizational Structures of Students' Unions}

The student organizations in the United States can be described as various and diverse. Among them, the student council (or "student government") is the most popular one. They are also the most well-organized student organizations in American universities with their members across the school. The student government in American universities would be mainly divided into three departments: an executive, a legislative and a judiciary. The organization, power and area of responsibility of each department are regulated by the statutes and regulations of the student council. As student societies in HK and Macao are highly autonomous, they could roll up their sleeves to strive for their promising future. Moreover, most student societies in HK and Macao are composed of undergraduates. They may be the combination of the students' union and federation of student societies of universities in mainland China in terms of the organizational structure. The HKUSU sets up a general meeting and a committee as well as an institute of arbitrators in accordance with the principle of separation of powers. The UMSU comprises General Assembly, Board of Directors and Supervisory Board. Besides, a presidium includes a president, a vice president and a secretary, all of whom shall not concurrently serve as administrative personnel in sub-organizations. The NTUSA, following the same principle with its counterpart in HK, is divided into three branches, an executive, a legislative (students' congress) and a judiciary (students' court), equipped with a president, a speaker and a chief student judge respectively.

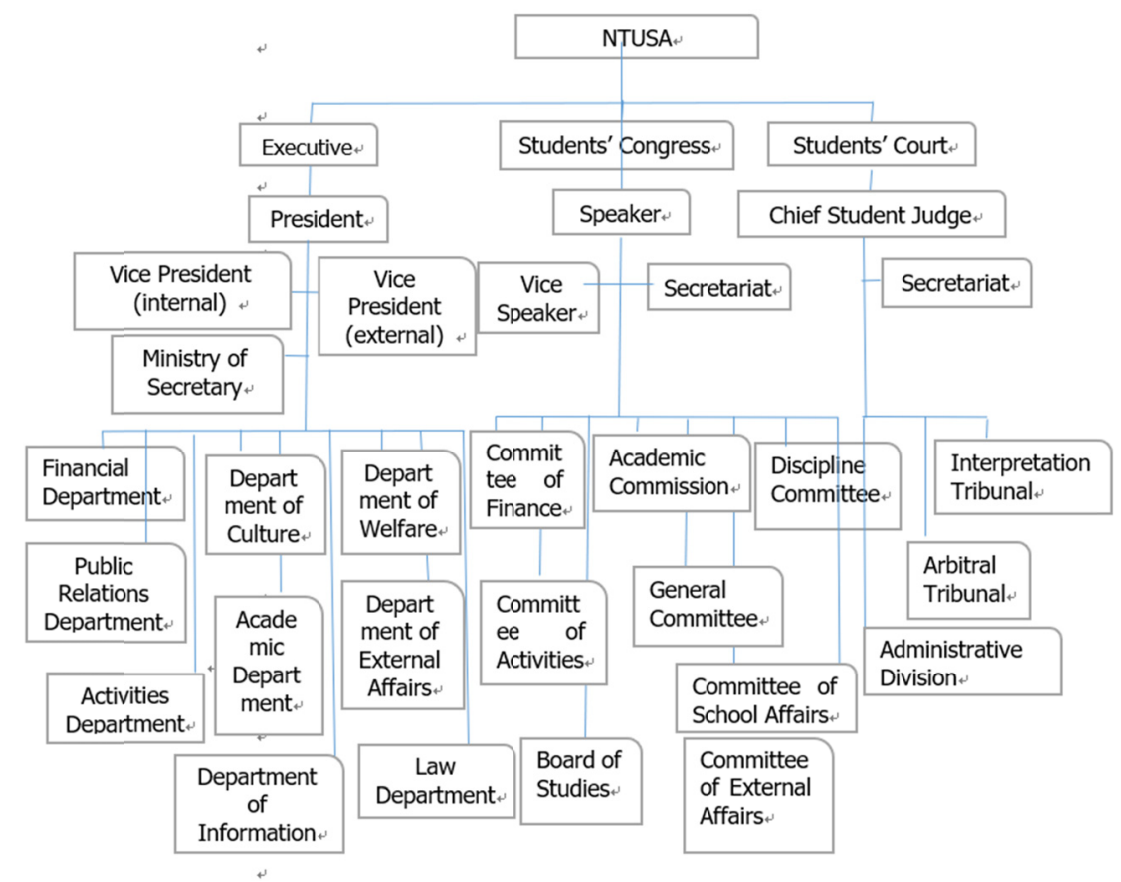

Figure 1. The Organization Structure of National Taiwan University Student Association

The organizational structure of university students' union is made up of a president, a vice president or general secretary, a minister and several assistant ministers for each department. The president takes charge of all affairs in a students' union. The vice president or general secretary assists the president. The ministers and assistant ministers put the tasks assigned by them in place. The students' congress represents the supreme organ of the power of a students' union, implementing the collective presidium accountability. (Liu \& Liu, 2012) Meanwhile, the students' union is divided into two levels, one is university-based and the other faculty-based (or departmentbased), with the latter leaded by both the former and the Party organization of the faculty (or department) while at the same time guided and assisted by the Youth League organization of the faculty (or department). 


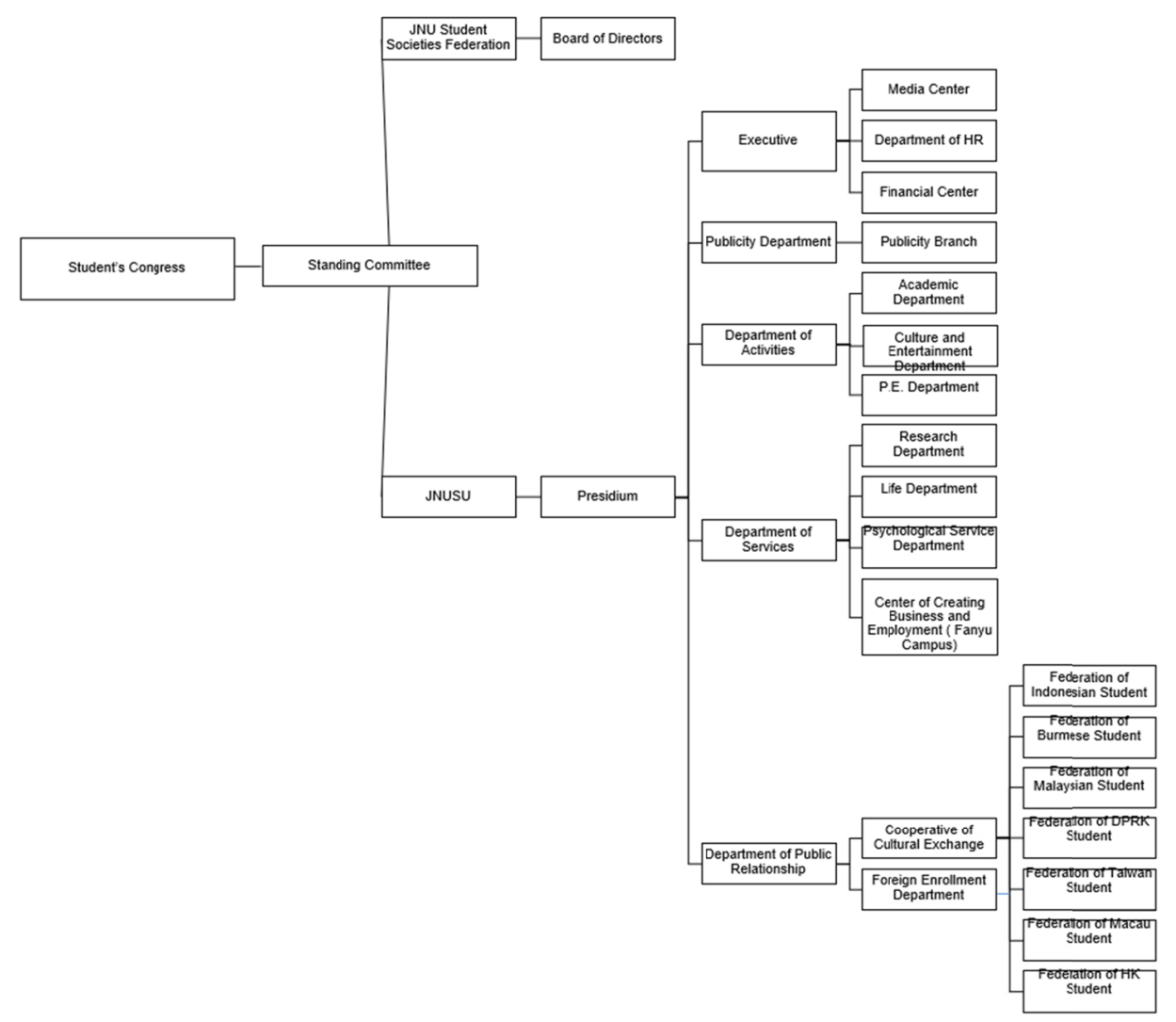

Figure 2. The Organization Structure of Jinan University Students' Union

\subsection{Form of Activity and Financial Source of Student Societies}

The university students' union outside mainland China is known for its mature rules and regulations on fund management, financial system and activity arrangement. What's more, they have sufficient funds. In America, the operation fund of university students' union mostly comes from membership dues. Apart from that, the fund would also be added by the donation from relevant departments of the university, foundations, alumnus, and social groups. (Liao, 2005) In addition, some universities have charted other accesses of finance. For example, to earn the running fee, Stanford University Students' Union has opened its own restaurant and bookstore, has organized movie show regularly, has conducted business of charter flights during summer and winter holidays and has collected the texts of key lectures for sale. The universities students' union in HK impose the model of independent organization, management, finance and operation. It has its own office building, cooperative, printing center, shop and company. The union has done such a good job in packaging and promotion, making full use of commercial techniques to enhance its influence and to attract attention from society, that it has absorbed certain investment from many alumnus and social organizations. Meanwhile, the grant from the university and the HK SAR Government, the profit from self-employed industries and financial investments also expand access to funds. Adequate capital enables the students' union to create novel and diverse activities, covering all aspects of campus life. Some have even become prestigious projects of activities about campus culture. All in all, running self-employed business empowers the organizations to carry out better activities, at the same time, created good opportunities for the student members gaining management experience.

Table 4. Contrast on Financial Source between University Students' Unions inside and Outside Mainland China

\begin{tabular}{|c|c|c|c|c|c|}
\hline Location of University & \multicolumn{5}{|c|}{ Financial Source } \\
\hline Mainland China & \multicolumn{5}{|c|}{$\begin{array}{l}\text { Mainly the fund is from the grant of university. Some influential students' unions have extra } \\
\text { social support. }\end{array}$} \\
\hline Outside Mainland China & $\begin{array}{l}\text { Membership dues or } \\
\text { registration fee of new } \\
\text { member }\end{array}$ & $\begin{array}{l}\text { Grant from } \\
\text { university or } \\
\text { government }\end{array}$ & $\begin{array}{c}\text { Social } \\
\text { support }\end{array}$ & $\begin{array}{l}\text { Profit of } \\
\text { self-employed } \\
\text { industries }\end{array}$ & $\begin{array}{l}\text { Pay campus } \\
\text { activity }\end{array}$ \\
\hline
\end{tabular}


On contrary, the operation fee has long been a bottleneck against the development of university students' union inside mainland China. Presently, there are two main financial sources for them, namely, grant from university and social support, with the former accounting for the leading part. In fact, the amount of fund determines the scale and the influence of campus activities. Compared with the counterpart outside mainland China, students' unions in mainland China are commonly under-socialized and under-commercialized. Their activity contents are often too simple, lack of innovation and attraction. Besides, the degree of financial investment and physical support on student societies vary from one university to another.

\subsection{Management and Development of Student Societies}

The advanced management of university student societies outside mainland China is not only acceptable but very conducive to the development of university student societies. Most American student societies launched a series of systems such as annual review system, activity report system and activity management system. Furthermore, they all have the improved "Management Principle of Student Societies", which enhances the management mechanism for student societies, facilitating their healthy and sustainable development. In Singapore, student societies at universities, guided by the department for student affairs, established a sound mechanism of organization and management, a mechanism of activity participation and an incentive mechanism. In addition, thanks to the e-commerce information technology, the student societies there has upgraded their working efficiency so much that they reached a paperless office. (Ji, 2010) In terms of student societies in Macao and HK, the management work is not guided but just assisted by the department for student affairs. Also, student societies in HK and Macao manage their affairs in an occupation style and they even launch some academic projects to strengthen their members' academic ability, which is similar to the management model of student societies in western developed countries.

In mainland China, university student societies have initiatively forged some relatively improved regulations and rules, such as the" Statute of the Student Society", "Duties and Work for Members of Student Societies", "Regulations on Membership Dues" and among others. But generally speaking, they still suffered the incomplete management system and outdated management ideas. Therefore, there is a big gap between student societies inside and outside mainland China, especially those from HK, Macao, Taiwan and western developed countries. As for the problems in the development of student societies, many student societies prepare no well-organized long-term regulation. Some spur-of-the-moment societies faded soon after the recruitment of new member. What's worse, student societies inside mainland China have few opportunities for international exchange and few connections with the society. To some extent, it is quite difficult for them to conduct the long-term and steady cooperation with corporates and social groups. The sustainable development of university student societies is heavily restrained then.

\section{Conclusion}

The multi-aspect comparison between student societies of universities of both sides witnessed the unique facet of student societies of universities in mainland China, but what's more important is, the disparity and the weak point. Hence, universities in mainland China should give the first priority to improving the management, both theoretically and practically, on student societies.

\subsection{Improving Management and System Establishment for Healthy Development}

The benign development of university student societies relies on a mature management system, comprising the statute of association, the administrative regulation, the incentive mechanism, the supervision mechanism and the training mechanism. Colleges and universities should practically increase their guidance to student societies, which may be fulfilled through conscientiously selecting responsible and professional teachers with high ideological awareness as supervisors to guide the operation in student associations while constantly improving their mechanism. Only in this way can we make it cater to the need of the development of student societies. Only in this way can we ensure the steady and sustainable development of student associations.

\subsection{Increasing Investment and Support to Strengthening Engagement in Society}

The diversity of activities held by university students' union outside mainland China depends largely on their ample funds, which comes from the impressive investment from universities and self-employed businesses. However, the limitations of the venues and material resources at most colleges and universities in mainland China lead to an uncertain effect for activities of student societies. Therefore, colleges and universities in mainland China should up their input in student societies, meaning that they should ease the access for the application for investment and venues of activities and infrastructure construction from the student societies. (Yu \& Han, 2002) In addition, colleges and universities should encourage student societies to carry out various 
public services so that they can receive support from the society and enterprises, making up for their weak points and raising engagement in society.

\subsection{Innovating the Contents of Activities with Characteristics for High Quality}

The activity of student societies is an important manifestation in the development of student societies, while the innovation in the activity is an inherent factor in the development of them. At present, colleges and universities in the Mainland should endeavor to attract and increase the participation of undergraduates in activities of student societies by carrying out activities frequently, developing the characteristics and exploring the innovative development model of student societies under the new situation. After that, student societies should highlight the activities peculiar to them and promote activities regularly at the same time. Selecting the essence of diverse cultures and discarding the dross, we need to nurture a society-oriented culture. Only if we make efforts like that, the student societies in universities can be empowered to develop prosperously. Step by step, the Chinese student societies can create campus culture with characteristics, high quality and prestige.

\subsection{Establishing International Platform While Opening up for Development}

University student societies inside and outside mainland China have been offering activities of mutual exchange to meet the requirements of training young students under new situation, for example, Cultural Tour for Youths of Guangdong Province, HK and Macao, Cross-Straits Four Regions Student Leaders Camp, China Root-seeking Summer Camp (with the latter two organized by JNU) and among other activities. As colleges and universities continue to intensify the management and service in activities of student societies, the concept of opening up in the exchange and development of student organizations has turned to be irreplaceable. Together with the concept of opening up, the deepening management on student societies is conducive to the students to make progress in various aspects: broadening their horizons; improving their overall quality and ability, registering an awareness of thinking in the long term while bearing the overall situation in mind and fostering a spirit of dedication to serving more students. As to colleges and universities, they should positively seek for international cooperation and strengthen the exchanges among university-based student societies, which will bring the all-round development to student societies, and, more importantly, increase their own influence.

\section{References}

Ji, H. Q. (2010). The Analysis and Enlightenment on Students' Work in Singapore. Modern Education Science, 1, 116-118.

Liao, L. H. (2005). Comparison of the Management on University Student Societies Between China and America - Taking the American Harvard University as a Case. Youth Research, 4, 45-48.

Liu, Y. H., \& Liu, G. R. (2012). The Contrastive Study and Enlightenment on University Student Societies between Taiwan and Mainland China. Higher Agricultural Education, 7, 93-95.

Yu, W., \& Han, L. Y. (2002). Comparison of Issues in the Construction of University Student Societies Between China and America. Studies in Foreign Education, 10, 57-60.

Zhu, F., Liu, W., \& Zhang, Q. (2008). The Status Quo and Operation of University Student Societies in Hong Kong and Their Influence on the Counterpart in Mainland China. Journal of Guangxi Youth Leaders College, 2, 26-28.

\section{Copyrights}

Copyright for this article is retained by the author(s), with first publication rights granted to the journal.

This is an open-access article distributed under the terms and conditions of the Creative Commons Attribution license (http://creativecommons.org/licenses/by/4.0/). 